Article

\title{
Oxidation Characteristics and Electrical Properties of Doped Mn-Co Spinel Reaction Layer for Solid Oxide Fuel Cell Metal Interconnects
}

\author{
Pingyi Guo *, Yongbiao Lai, Yong Shao, Yu Zhang, Hang Sun and Yuxin Wang * (i) \\ School of Materials Science and Engineering, Jiangsu University of Science and Technology, Zhenjiang 212003, \\ China; yaoxuxuyao@163.com (Y.L.); shy782004@163.com (Y.S.); cantabile01@sohu.com (Y.Z.); \\ yxxyao@126.com (H.S.) \\ * Correspondence: pyguo@just.edu.cn (P.G.); ywan943@163.com (Y.W.); Tel.: +86-150-5291-9636 (P.G.); \\ Fax: +86-511-8440-7381 (P.G.)
}

Received: 7 December 2017; Accepted: 16 January 2018; Published: 22 January 2018

\begin{abstract}
To prevent $\mathrm{Cr}$ poisoning of the cathode and to retain high conductivity during solid oxide fuel cell (SOFC) operation, $\mathrm{Cu}$ or La doped Co-Mn coatings on a metallic interconnect is deposited and followed by oxidation at $750{ }^{\circ} \mathrm{C}$. Microstructure and composition of coatings after preparation and oxidation is analyzed by X-ray diffraction (XRD) and scanning electron microscopy (SEM). High energy micro arc alloying process, a low cost technique, is used to prepare $\mathrm{Cu}$ or La doped Co-Mn coatings with the metallurgical bond. When coatings oxidized at $750{ }^{\circ} \mathrm{C}$ in air for $20 \mathrm{~h}$ and $100 \mathrm{~h}$, $\mathrm{Co}_{3} \mathrm{O}_{4}$ is the main oxide on the surface of Co-38Mn-2La and Co-40Mn coatings, and $(\mathrm{Co}, \mathrm{Mn})_{3} \mathrm{O}_{4}$ spinel continues to grow with extended oxidation time. The outmost scales of $\mathrm{Co}-33 \mathrm{Mn}-17 \mathrm{Cu}$ are mainly composed of cubic $\mathrm{MnCo}_{2} \mathrm{O}_{4}$ spinel with $\mathrm{Mn}_{2} \mathrm{O}_{3}$ after oxidation for $20 \mathrm{~h}$ and $100 \mathrm{~h}$. The average thickness of oxide coatings is about $60-70 \mu \mathrm{m}$ after oxidation for $100 \mathrm{~h}$, except that $\mathrm{Co}-40 \mathrm{Mn}$ oxide coatings are a little thicker. Area-specific resistance of $\mathrm{Cu} / \mathrm{La}$ doped Co-Mn coatings are lower than that of $\mathrm{Co}-40 \mathrm{Mn}$ coating. $(\mathrm{Mn}, \mathrm{Co})_{3} \mathrm{O}_{4} / \mathrm{MnCo}_{2} \mathrm{O}_{4}$ spinel layer is efficient at blocking the outward diffusion of chromium and iron.
\end{abstract}

Keywords: copper; lanthanum; coating; in-situ oxidation; electrical properties

\section{Introduction}

Co-Mn-based spinel coatings and conversion coatings are the potential candidates for metallic interconnect coating materials of solid oxide fuel cell (SOFC) [1-5]. Some techniques have been applied to prepare these coatings such as electrophoretic deposition, plasma spraying, dip-coating, sol-gel method, screen printing, and physical vapor deposition. The high energy micro arc alloying process (HEMAA) [6-8] is a low cost technique to produce metallurgically bonded coatings. It is economically attractive for coating preparation to significantly reduce the cost of SOFC. In previous study [9], the $\mathrm{Cr} /$ La alloying layer is successively obtained on 430 stainless steel (SS) surface by HEMAA using metallic $\mathrm{Cr}$ electrode and metallic La electrode, respectively. The result shows that a good protective perovskite coating with an acceptable electrical contact resistance forms on the substrate steel after coating is thermally grown.

Reactive elements have been added to improve the high temperature oxidation characteristics of Co-Mn-based coatings. Mn-Co-Y-O spinel coatings [10] were prepared on AISI 430 and Crofer 22 APU steels by the magnetron sputtering. A combined Ce/Co alloy coatings [11] were deposited on metallic interconnects by physical vapor deposition process, and $\mathrm{Co} / \mathrm{CeO}_{2}$ composite coatings [12] were electroplated on the ferritic stainless steels Crofer 22 APU and Crofer $22 \mathrm{H}$. Lanthanum (La) is usually synthesized as perovskite cathode and interconnect material for intermediate temperature solid 
oxide fuel cell [13-16]. High temperature oxidation characteristics of active element Lanthanum have been investigated in alloys. The result shows that the formation of La oxides remarkably improves oxidation resistance of alloys [17,18].

The dopant of $\mathrm{Cu}$ and/or Ni into Mn-Co spinel generally affects the high temperature properties of spinel oxide because of crystal structure and phase of spinel oxide after sintering changed [19,20]. $\mathrm{Cu}$ doped Mn-Co oxide was sintered into pellets after the High Energy Ball Milling process [21]. The results show that cubic Mn-Co spinel stability, spinel sintering behavior and electrical conductivity are improved by $\mathrm{Cu}$ addition. $\mathrm{Cu}-\mathrm{Mn}$-Co spinel coatings prepared via the slurry dip-coating $[20,22,23]$ and the screen-printing technique [24] exhibit high electrochemical performance and oxidation characteristics. However, the adherence to substrate for spinel coatings is still a problem. HEMAA process [25] produces the metallurgically bonded alloy coatings and forms spinel coatings via in situ oxidation.

In this test, lanthanum/copper added into Co-Mn spinel coating for metallic interconnect is studied in detail. This work aims to investigate high-temperature oxidation characteristics and electrical properties of Co-33Mn-17Cu and Co-38Mn-2La coatings prepared by HEMAA for intermediate temperature SOFC interconnects application.

\section{Experimental}

For the experiment, $430 \mathrm{SS}$ is used as substrate alloy with composition 16-18 Cr, $1 \mathrm{Mn}, 0.12 \mathrm{C}$, $0.75 \mathrm{Si}, 0.03 \mathrm{~S}, 0.04 \mathrm{P}, 0.06 \mathrm{Ni}$ and balance Fe (wt.\%). Co-33Mn-17Cu, Co-38Mn-2La and Co-40Mn (at.\%) alloy is at first prepared by argon arc melting of high purity metals (99.99 wt.\%). Then, alloy ingots are cut into rods and the diameter is about $3.0 \mathrm{~mm}$ used as Co-33Mn-17Cu, Co-38Mn-2La and Co-40Mn electrodes (anodes for HEMAA process). All electrodes are ground up and then degreased with acetone. Deposition parameters of coatings [3,8,26] are $110 \mathrm{~V}, 900 \mathrm{~Hz}$ and 1000-1200 W.

Oxidation measurement for deposited coatings is carried out at $750{ }^{\circ} \mathrm{C}$ in air for $20 \mathrm{~h}$ and $100 \mathrm{~h}$. Area specific resistance (ASR) measurement of Co-33Mn-17Cu, Co-38Mn-2La and Co-40Mn coatings after oxidation is performed by the four-probe direct current (DC) method [3,8]. The applied voltage is $5 \mathrm{~V}$ and contact area of Pt electrode is about $10 \mathrm{~mm}^{2}$ bonding with Pt paste. The measured sample is placed in the constant temperature zone of horizontal tube furnace at room temperature, and then is heated up to setting temperature $\left(500-800{ }^{\circ} \mathrm{C}\right)$. The value of ASR is taken when every setting temperature keeps steady.

X-ray diffractometer (XRD, D/MAX-3B, Rigaku Co., Tokyo, Japan) is conducted for phase analyses, and surface roughness analyses are performed by 3D microscope (VHX-900, KEYENCE, Tokyo, Japan) on the top surfaces. Specimens are mounted in a cold-setting epoxy resin to avoid cracking and give support for polishing. Cross-section surfaces and quantitative elemental analyses are examined by scanning electron microscopy (SEM, JSM-5800, JEOL, Tokyo, Japan) with energy dispersive X-ray spectroscopy (EDS).

\section{Results and Discussion}

\subsection{Microstructural Studies of Coated Samples}

Figure 1a shows that Co-38Mn-2La alloy (electrode) is a two-phase structure composed of a Co-based solid solution and an La-rich phase (light phase), which is most localized at grain boundaries. EDS analysis on Co-38Mn-2La alloy reveals that the concentrations of Co and Mn in solid solution are 63.96 and 36.04 in at.\%. Figure $1 \mathrm{~b}$ shows that a continuous Co-38Mn-2La coating has been produced on the substrate surface with a metallurgical bonding and the average thickness of coating is about $30 \mu \mathrm{m}$. Figure $1 \mathrm{c}$ shows that Co-33Mn-17Cu alloy is composed of a Co-rich phase and a Cu-rich phase (light phase). EDS reveals that $\mathrm{Cu}$ concentration is about 40.4 at.\% in the $\mathrm{Cu}$-rich phase. Figure $1 \mathrm{~d}$ shows the continuous Co-33Mn-17Cu coating is deposited and the interface keeps good adherence to the substrate. 


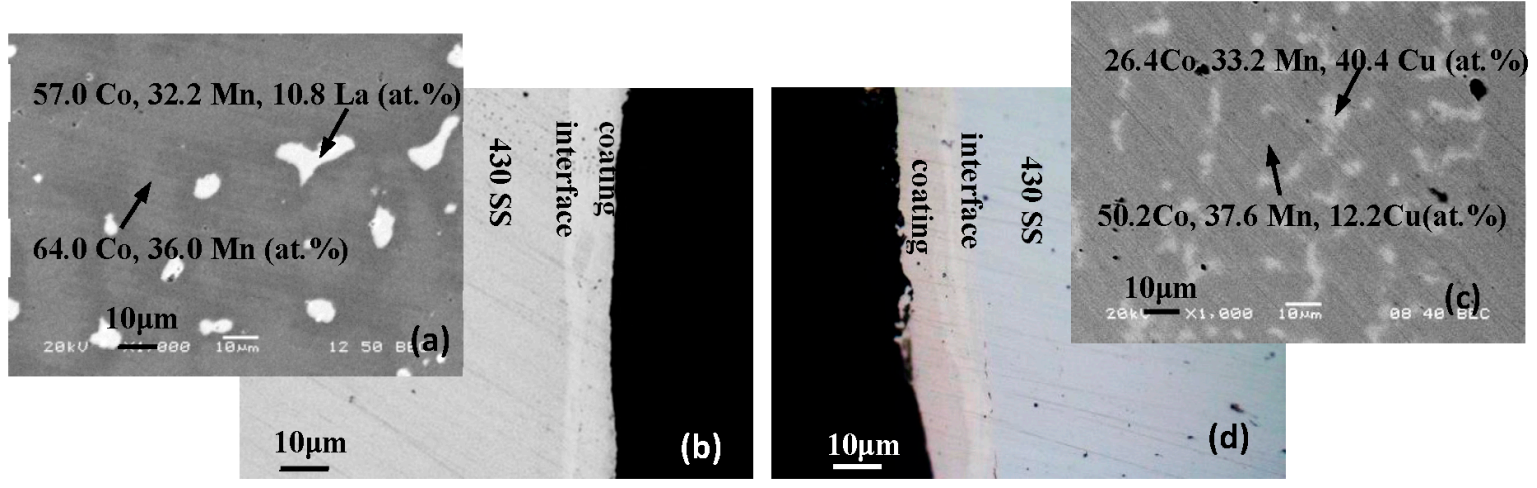

Figure 1. (a) Morphology of Co-38Mn-2La alloy; (b) cross section of Co-38Mn-2La coating deposited by high energy micro arc alloying process (HEMAA); (c) morphology of Co-33Mn-17Cu alloy and (d) cross section of Co-33Mn-17Cu coating deposited by HEMAA.

\subsection{Microstructures of Oxide Coatings on the Metallic Interconnects}

Figure 2 shows X-ray diffraction and surface morphology of coatings oxidized at $750{ }^{\circ} \mathrm{C}$ for $20 \mathrm{~h}$ and $100 \mathrm{~h}$. Before oxidation, Co-38Mn-2La alloy coating in Figure 2a is mainly a cubic Co structure and peaks shift toward low angles by referring to pure Co When coating oxidized at $750{ }^{\circ} \mathrm{C}$ in air for $20 \mathrm{~h}$, the outmost scales in Figure $2 \mathrm{~b}$ combined with EDS analysis consist of $\mathrm{Co}_{3} \mathrm{O}_{4}$ and small amount of $(\mathrm{Co}, \mathrm{Mn})_{3} \mathrm{O}_{4}$, which is an intermediate tetragonal spinel structure between $\mathrm{MnCo}_{2} \mathrm{O}_{4}$ (cubic) and $\mathrm{Mn}_{3} \mathrm{O}_{4}$ (tetragonal). The previous study [25] discloses that $\mathrm{Co}_{3} \mathrm{O}_{4}$ prefer to form under high oxygen partial pressure and only a thin layer is found on the top oxide layer. When Co-38Mn-2La coating oxidized for $100 \mathrm{~h}$, diffraction peak of tetragonal $(\mathrm{Co}, \mathrm{Mn})_{3} \mathrm{O}_{4}$ spinel is intensified in Figure 2c, due to Mn outer-diffusion with the extended time.

Before oxidation, $\mathrm{Co}-33 \mathrm{Mn}-17 \mathrm{Cu}$ alloy coating in Figure $2 \mathrm{~d}$ is mainly $\mathrm{Cu}$ characteristic peak. After oxidation for $20 \mathrm{~h}$ in Figure 2e, the outmost scales combined with EDS analysis are mainly composed of cubic $\mathrm{MnCo}_{2} \mathrm{O}_{4}$ spinel with $\mathrm{Mn}_{2} \mathrm{O}_{3}$ oxide. The same $\mathrm{MnCo}_{2} \mathrm{O}_{4}$ and $\mathrm{Mn}_{2} \mathrm{O}_{3}$ diffraction peaks are also detected after Co-33Mn-17Cu coating oxidized for $100 \mathrm{~h}$ in Figure 2f. Oxidation products of Co-40Mn coating after $20 \mathrm{~h}$ and $100 \mathrm{~h}$ in Figure 2g,h are the same as Co-38Mn-2La coating.

Figure $2 \mathrm{f}_{1}$ shows surface morphology of Co-33Mn-17Cu coating oxidized for $100 \mathrm{~h}$, which is a typical spinel structure. Element distributions in Table 1 indicate the trace amount of Fe and $\mathrm{Cr}$ detected on the oxide surface. Figure $2 b_{1}, b_{2}$ show surface morphology of Co-38Mn-2La coating oxidized for $20 \mathrm{~h} . \mathrm{Co}_{3} \mathrm{O}_{4}$ is the main oxides with some fine pores. The size of pores is correlation with $\mathrm{Mn}$ content of $\mathrm{Co}_{3} \mathrm{O}_{4}$ oxides and will shrink with $\mathrm{Mn}$ content increasing [8]. $\mathrm{Co}_{3} \mathrm{O}_{4}$ scale formed on the surface is a cubic spinel structure with Mn content 5.6 at.\% from XRD and EDS analysis in Table 1, which means the scale is a Co-rich Co-Mn spinel phase. Some granular appearance in Figure $2 b_{2}$ is also seen on the surface and EDS in Table 1 shows that element compositions are the same as Figure $2 b_{1}$. It is hypothesized that the granular $\mathrm{Co}_{3} \mathrm{O}_{4}$ found in local area is due to active element Lanthanum enrichment, which is found in Co-38Mn-2Dy coating but not for Co-40Mn coating [25]. When coating oxidized for $100 \mathrm{~h}$, fine pores and needle-like morphology in Figure $2 \mathrm{c}_{1}$ are visible and uniformly distributed in $\mathrm{Co}_{3} \mathrm{O}_{4}$ scales. $(\mathrm{Co}, \mathrm{Mn})_{3} \mathrm{O}_{4}$ scales in Figure $2 \mathrm{c}_{2}$ are the typical spinel structure and $\mathrm{Mn}$ content in $(\mathrm{Co}, \mathrm{Mn})_{3} \mathrm{O}_{4}$ is higher than in $\mathrm{MnCo}_{2} \mathrm{O}_{4}$ spinel in Table 1, which is in accordance with XRD analysis. The granular appearance is not found after Co-38Mn-2La coating oxidized for $100 \mathrm{~h}$. Surface morphology of Co-40Mn coating oxidized for $20 \mathrm{~h}$ and $100 \mathrm{~h}$ is showed in Figure $2 \mathrm{~g}_{1}, \mathrm{~h}_{1}$. It is the same morphology as Co-38Mn-2La coating except for the granular appearance. 

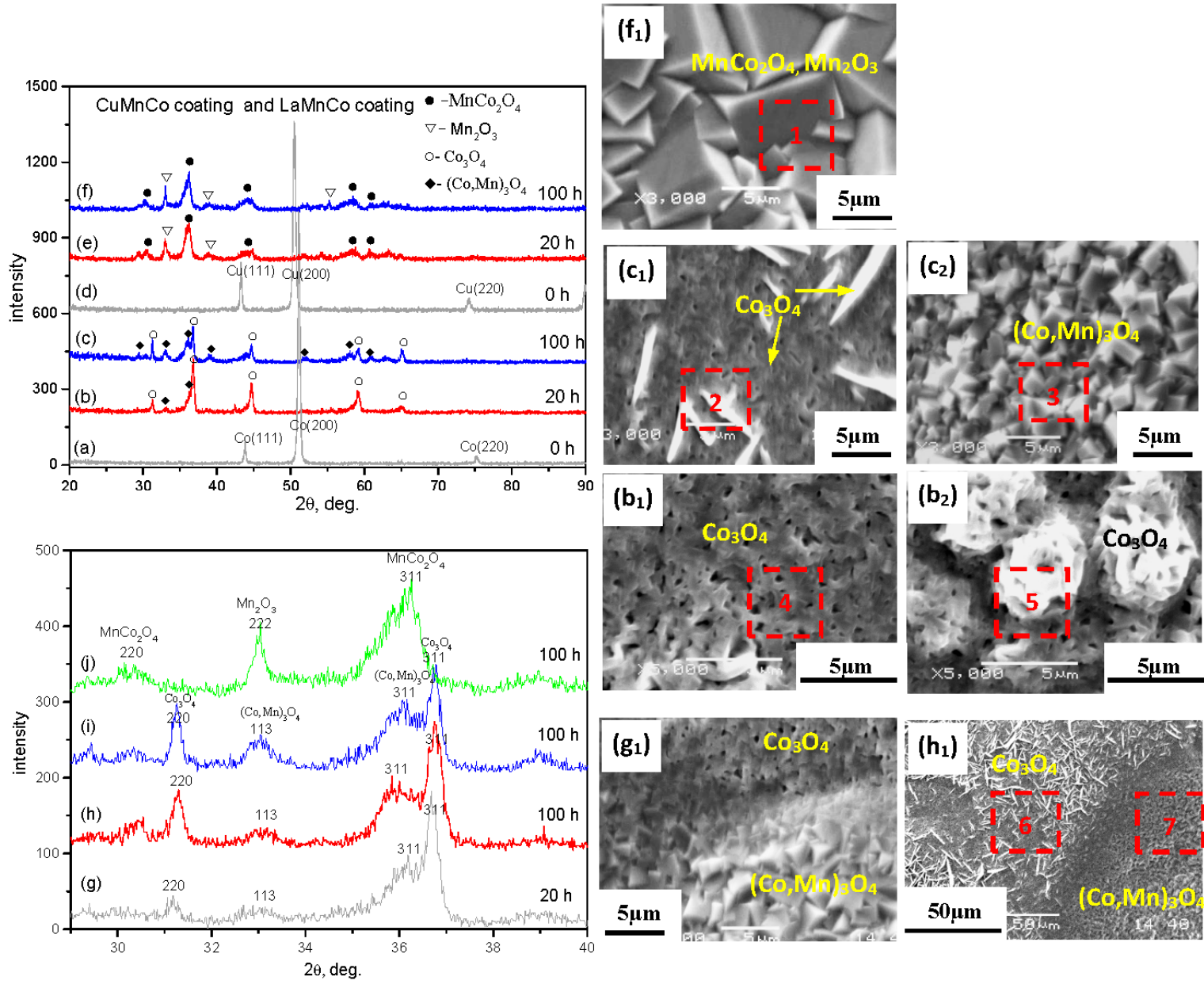

Figure 2. X-ray diffraction and surface morphology of coatings deposited by HEMAA oxidized at $750{ }^{\circ} \mathrm{C}$ in air. (a-c) Co-38Mn-2La coating oxidized for $0 \mathrm{~h}, 20 \mathrm{~h}$ and $100 \mathrm{~h}$; (d-f) Co-33Mn-17Cu coating oxidized for $0 \mathrm{~h}, 20 \mathrm{~h}$ and $100 \mathrm{~h}$; (g,h) Co-40Mn coating oxidized for $20 \mathrm{~h}$ and $100 \mathrm{~h}$; (i) Co-38Mn-2La coating oxidized for $100 \mathrm{~h}$; (j) Co-33Mn-17Cu coating oxidized for $100 \mathrm{~h} ;\left(\mathbf{f}_{\mathbf{1}}\right)$ surface morphology of Co-33Mn-17Cu coating oxidized for $100 \mathrm{~h} ;\left(\mathbf{c}_{1}, \mathbf{c}_{2}\right)$ and $\left(\mathbf{b}_{1}, \mathbf{b}_{2}\right)$ surface morphology of Co-38Mn-2La coating oxidized for $100 \mathrm{~h}$ and $20 \mathrm{~h} ;\left(\mathbf{g}_{1}\right)$ and $\left(\mathbf{h}_{\mathbf{1}}\right)$ surface morphology of Co-40Mn coating oxidized for $20 \mathrm{~h}$ and $100 \mathrm{~h}$.

Table 1. Composition analysis by energy dispersive X-ray spectroscopy (EDS) of local region in Figure 2.

\begin{tabular}{cccccccc}
\hline Element, at. \% & Co & Mn & Cu & Fe & Cr & La & O \\
\hline Area 1 & 11.5 & 27.2 & 6.6 & 0.7 & - & - & 53.9 \\
Area 2 & 43.4 & 5.4 & - & - & - & - & 51.2 \\
Area 3 & 15.5 & 17.9 & - & - & - & - & 66.6 \\
Area 4 & 35.5 & 5.6 & - & - & - & - & 58.9 \\
Area 5 & 37.2 & 5.2 & - & - & - & - & 57.5 \\
Area 6 & 36.5 & 5.3 & - & - & - & - & 58.1 \\
Area 7 & 25.6 & 22.5 & - & - & - & - & 51.9 \\
\hline
\end{tabular}

Figure 3 shows that mass gain of Co-33Mn-17Cu coating is smallest when coatings oxidized for $20 \mathrm{~h}$ and followed by Co-38Mn-2La coating. However, after oxidation for $100 \mathrm{~h}$ mass gain of three coatings is almost overlapped. 


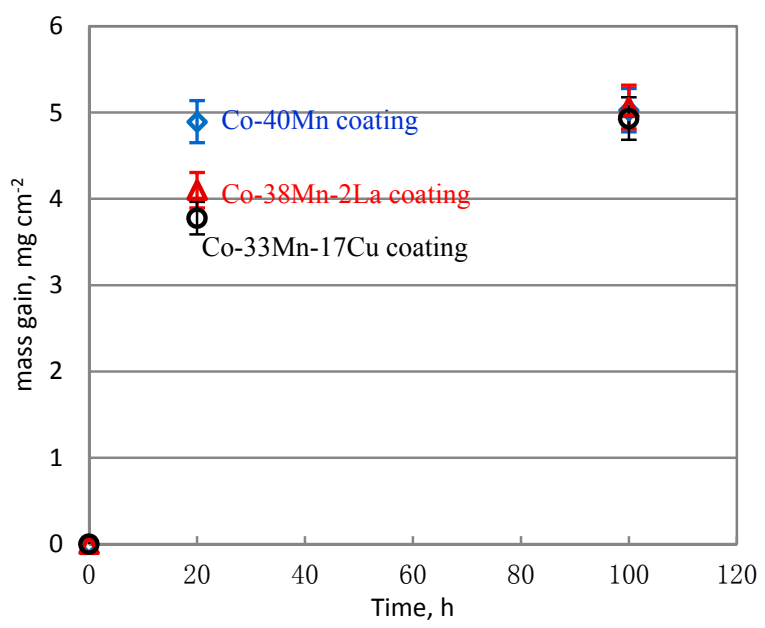

Figure 3. Mass gain of oxidized coatings at $750{ }^{\circ} \mathrm{C}$ in air.

Figure 4 shows cross section (back-scattered electron image) and EDS line scanning of Co-38Mn-2La coating oxidized at $750{ }^{\circ} \mathrm{C}$ in air for $100 \mathrm{~h}$. Oxide coating is compact and good adherence to $430 \mathrm{SS}$ substrate. The average thickness of coating is about $64 \mu \mathrm{m}$. Figure $4 \mathrm{a}_{1}$ shows cross-section morphology of $\mathrm{Co}_{3} \mathrm{O}_{4}$ on the top oxide layer and an Mn-rich oxide layer under the $\mathrm{Co}_{3} \mathrm{O}_{4}$ layer. Figure $4 \mathrm{a}_{2}$ shows cross-section morphology of $(\mathrm{Co}, \mathrm{Mn})_{3} \mathrm{O}_{4}$ scales on the top oxide layer. EDS indicates that light phases precipitating in the oxide coating in Figure $4 \mathrm{a}_{2}$ are La-rich oxides. According to line scanning analysis, $\mathrm{Mn}$ is enriched in the vicinity of the top oxide layer and Co content is homogeneous in the oxide coating. Enrichment of $\mathrm{Cr}$ is detected in the oxide/substrate interface, and $\mathrm{Cr}$ content is very low in the coating. Fe outward diffusion is found in the oxide coating in Table 2.

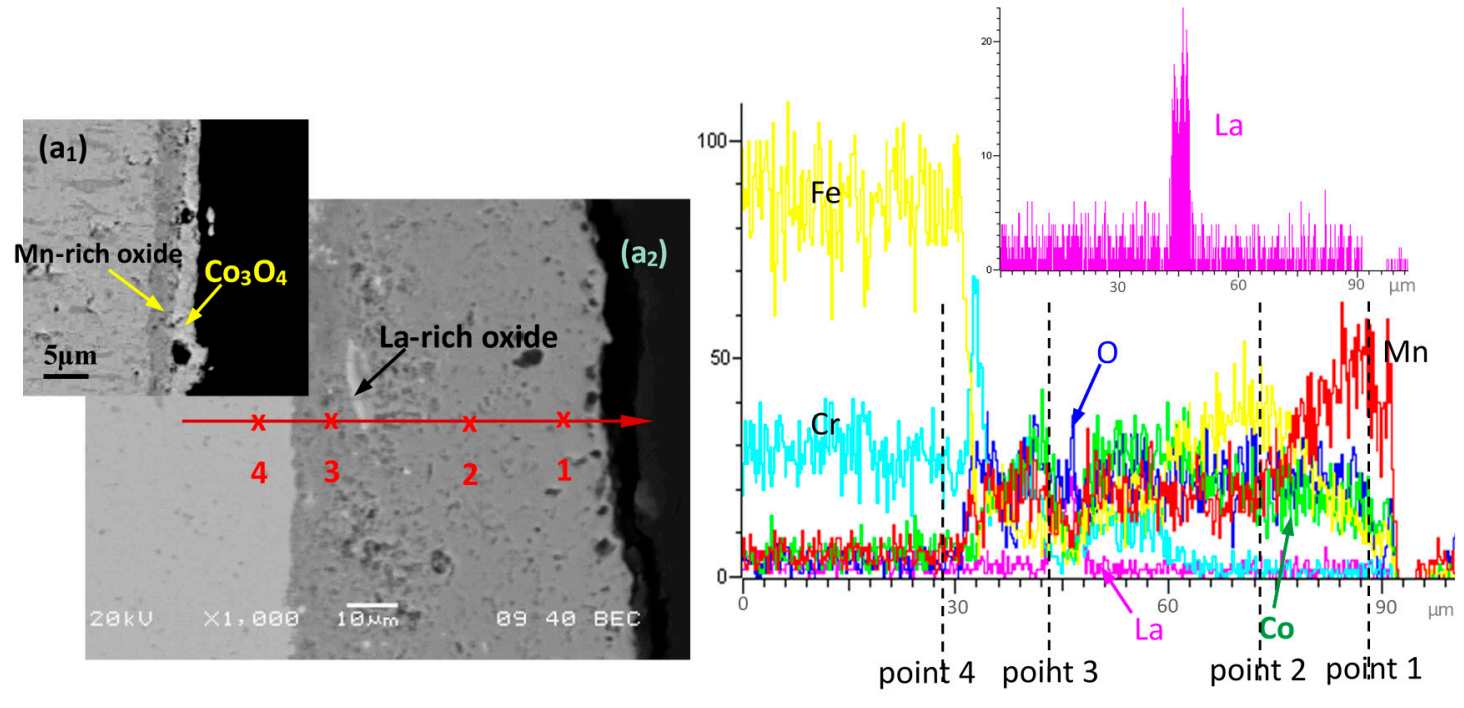

(a)

(b)

Figure 4. Cross-section morphology and EDS line scanning of Co-38Mn-2La coating oxidized at $750{ }^{\circ} \mathrm{C}$ in air for $100 \mathrm{~h}$. The line scan position is shown in the cross-sectional image. (a) Cross section; (b) EDS line scanning. 
Table 2. Composition analysis by EDS of the local region in Figure 4.

\begin{tabular}{ccccccc}
\hline Point, at. $\%$ & Co & Mn & Fe & Cr & La & O \\
\hline 1 & 11.75 & 35.39 & 1.38 & - & - & 51.58 \\
2 & 16.08 & 10.32 & 16.43 & 1.69 & - & 55.47 \\
3 & 24.96 & 12.99 & 3.63 & 3.63 & - & 54.79 \\
4 & 4.73 & - & 80.28 & 15 & - & - \\
\hline
\end{tabular}

Cross-section morphology of Co-33Mn-17Cu coating oxidized for $100 \mathrm{~h}$ is showed in Figure 5. Some micro-pores are found in scales due to the formation of abundant spinel oxide and diffusion of elements. Similarly, coating keeps good adherence to the substrate and its average thickness is 60-70 $\mu \mathrm{m}$. The line scan discloses the outer part of oxide layer rich in $\mathrm{Mn}$ and Co concentrate increasing slightly in the inner oxide layer. The aggregation of element $\mathrm{Cu}$ near the surface is not obviously detected. Element $\mathrm{Fe} / \mathrm{Cr}$ outward diffusion behavior (Table 3) is analogous to the Co-38Mn-2La oxide layer.
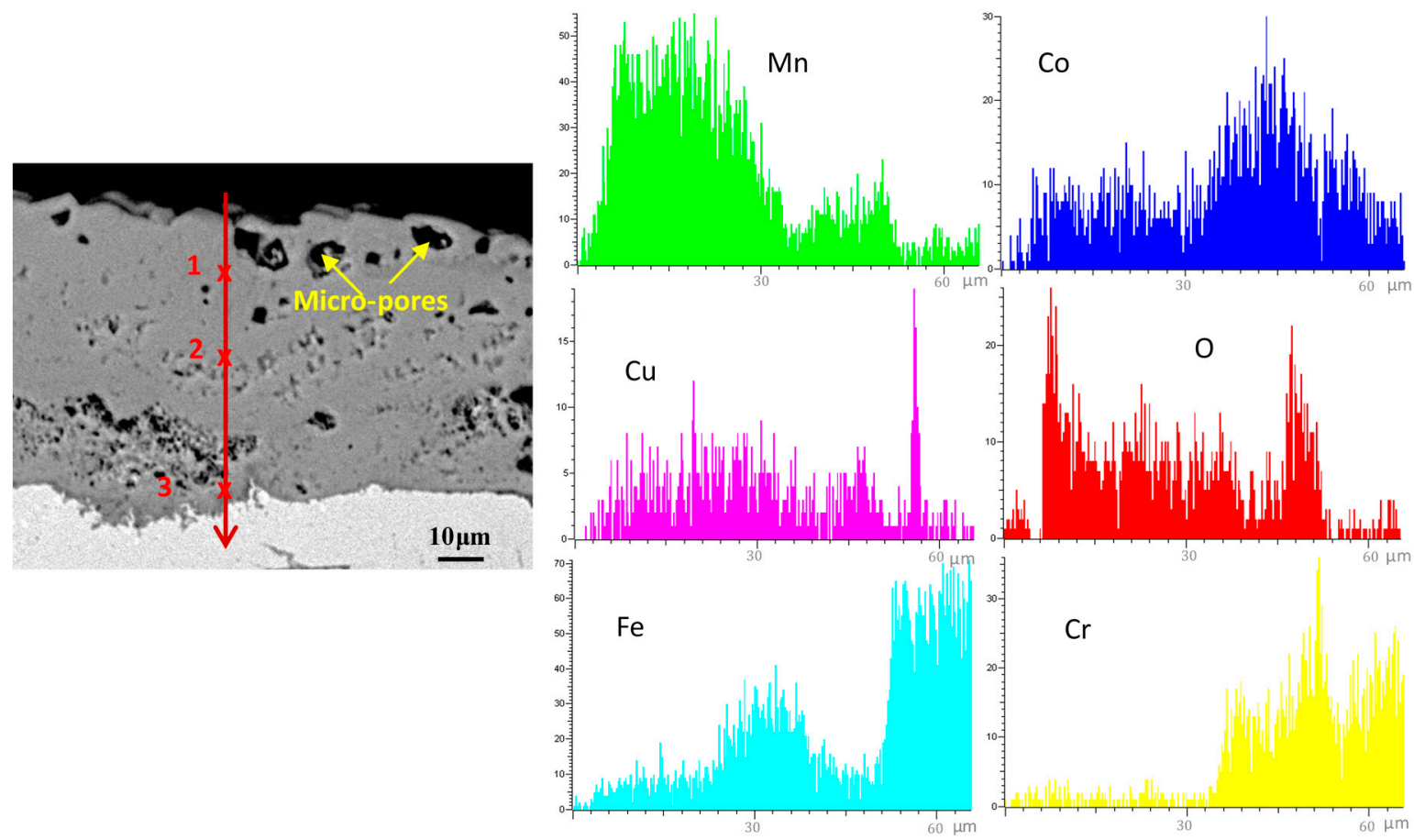

Figure 5. Cross-section morphology and EDS line scanning of Co-33Mn-17Cu coating oxidized at $750{ }^{\circ} \mathrm{C}$ in air for $100 \mathrm{~h}$. The line scan position is shown in the cross-sectional image.

Table 3. Composition analysis by EDS of the local region in Figure 5.

\begin{tabular}{ccccccc}
\hline Point, at. $\%$ & Co & Mn & Cu & Fe & Cr & O \\
\hline 1 & 12.0 & 39.4 & 3.7 & 2.8 & - & 42.1 \\
2 & 10.9 & 21.9 & 4.3 & 26.2 & - & 36.7 \\
3 & 20.0 & 9.2 & 5.0 & 6.4 & 10.0 & 49.4 \\
\hline
\end{tabular}

Cross-section morphology of Co-40Mn coating oxidized for $100 \mathrm{~h}$ in Figure 6 shows $\mathrm{Co}_{3} \mathrm{O}_{4}$-rich layer on the outmost oxides, and Mn-rich oxide layer is still next to the $\mathrm{Co}_{3} \mathrm{O}_{4}$ layer, which is the typical morphology for Co-38Mn-2La and Co-40Mn coatings. Fe content is also high in local area (point 4, Table 4). Additionally, the average thickness of $\mathrm{Co}-40 \mathrm{Mn}$ oxide coating with a $\mathrm{Co}_{3} \mathrm{O}_{4}$-rich layer is larger than that of Co-38Mn-2La and Co-33Mn-17Cu oxide coating. 

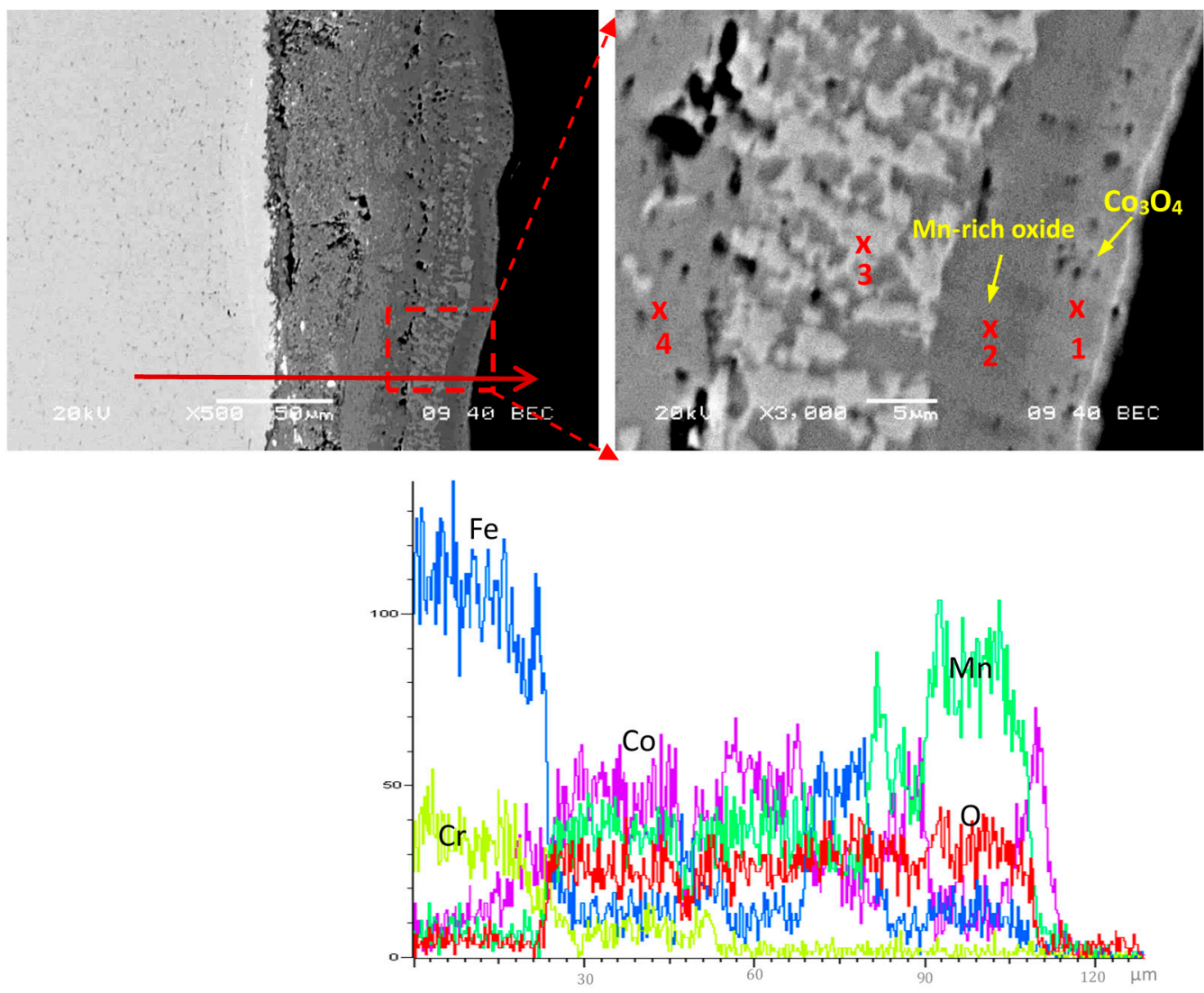

Figure 6. Cross-section morphology and EDS line scanning of Co-40Mn coating oxidized at $750{ }^{\circ} \mathrm{C}$ in air for $100 \mathrm{~h}$. The line scan position is shown in the cross-sectional image.

Table 4. Composition analysis by EDS of the local region in Figure 6.

\begin{tabular}{cccccc}
\hline Point, at. $\%$ & Co & Mn & Fe & Cr & O \\
\hline 1 & 29.1 & 7.0 & - & - & 63.9 \\
2 & 6.9 & 37.2 & 1.9 & - & 54.1 \\
3 & 34.6 & 16.4 & - & - & 49.0 \\
4 & 10.9 & 9.5 & 23.1 & - & 56.5 \\
\hline
\end{tabular}

\subsection{ASR Measurements}

Co-38Mn-2La coating after oxidation for $100 \mathrm{~h}$ is showed in Figure 7. The surface of oxide coatings is generally highly irregular due to the HEMAA process, and surface microtopography and roughness of oxides for three coatings are close. The values of surface roughness disclose that surface become relative smooth with extended oxidation time. Arithmetical average roughness height $\left(S_{\mathrm{a}}\right)$ of Co-38Mn-2La oxide coating is about $7.21 \mu \mathrm{m}$ for $0 \mathrm{~h}, 6.34 \mu \mathrm{m}$ after oxidation for $20 \mathrm{~h}$ and $5.53 \mu \mathrm{m}$ for $100 \mathrm{~h}$. Measurement of area specific resistance is bonded with Pt paste, and the value is little affected by surface roughness.

ASR of three coatings after oxidation at $750{ }^{\circ} \mathrm{C}$ for $20 \mathrm{~h}$ and $100 \mathrm{~h}$ is showed in Figure 8 . All ASR values decrease gradually with increasing temperature from 500 to $800{ }^{\circ} \mathrm{C}$. It is typical for electric conductivity of a semiconductor oxide as a function of temperature [24,27], in good agreement with the results of Mn-Co-based spinel in literature. ASR can make a corresponding response to the electrical conductivity and thicknesses of thermally grown oxide layers. Thus, ASR of three coatings after oxidation for $100 \mathrm{~h}$ is usually a little higher than that for $20 \mathrm{~h}$, especially at low temperature, such as $500{ }^{\circ} \mathrm{C}$ and $600^{\circ} \mathrm{C}$. ASR of Co-40Mn oxide coating is the largest among three oxide coatings for both 
$100 \mathrm{~h}$ and $20 \mathrm{~h}$ (Figure 8, line 1 and line 2), ASR of Co-38Mn-2La oxide coating (line 3 and line 4) is smaller than that of Co-40Mn oxide coating, and ASR of Co-33Mn-17Cu oxide coating stays the smallest. Especially when Co-33Mn-17Cu oxide coating oxidized for $20 \mathrm{~h}$, ASR values at low temperature keep in a very small range (line 6). ASR at $800{ }^{\circ} \mathrm{C}$ of Co-40Mn oxide coating is $79.2 \mathrm{~m} \Omega \mathrm{cm}^{2}$ for $20 \mathrm{~h}$ and $43.2 \mathrm{~m} \Omega \mathrm{cm}^{2}$ for $100 \mathrm{~h}$, the value obviously decreasing with oxidation time. The reason may be that the structure and composition of oxide products change along with oxidation time, such as some (Co,Mn $)_{3} \mathrm{O}_{4}$ spinel forming. ASR at $800{ }^{\circ} \mathrm{C}$ for Co-38Mn-2La oxide coating is about $19.6 \mathrm{~m} \Omega \mathrm{cm}^{2}$ for $20 \mathrm{~h}$ and $24 \mathrm{~m} \Omega \mathrm{cm}^{2}$ for $100 \mathrm{~h}$, the value slowly increasing with oxidation time. ASR at $800{ }^{\circ} \mathrm{C}$ for Co-33Mn-17Cu oxide coating is about $7.5 \mathrm{~m} \Omega \mathrm{cm}^{2}$ for $20 \mathrm{~h}$ and $41 \mathrm{~m} \Omega \mathrm{cm}^{2}$ for $100 \mathrm{~h}$, the value obviously increasing with oxidation time. The reason has not been discussed in detail, but, according to existing results, it may be the formation of many isolated micro-pores for $100 \mathrm{~h}$ in the oxide layer, besides the thickness increasing.
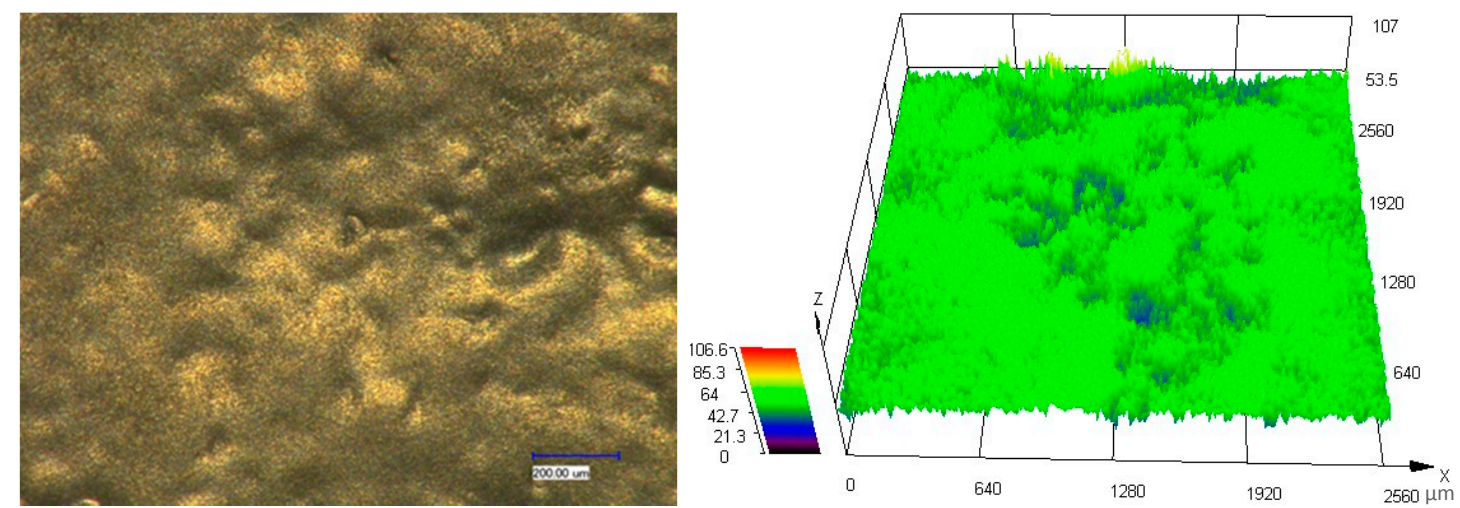

Figure 7. Surface microtopography and roughness of Co-38Mn-2La coating oxidized at $750{ }^{\circ} \mathrm{C}$ in air for $100 \mathrm{~h}$.

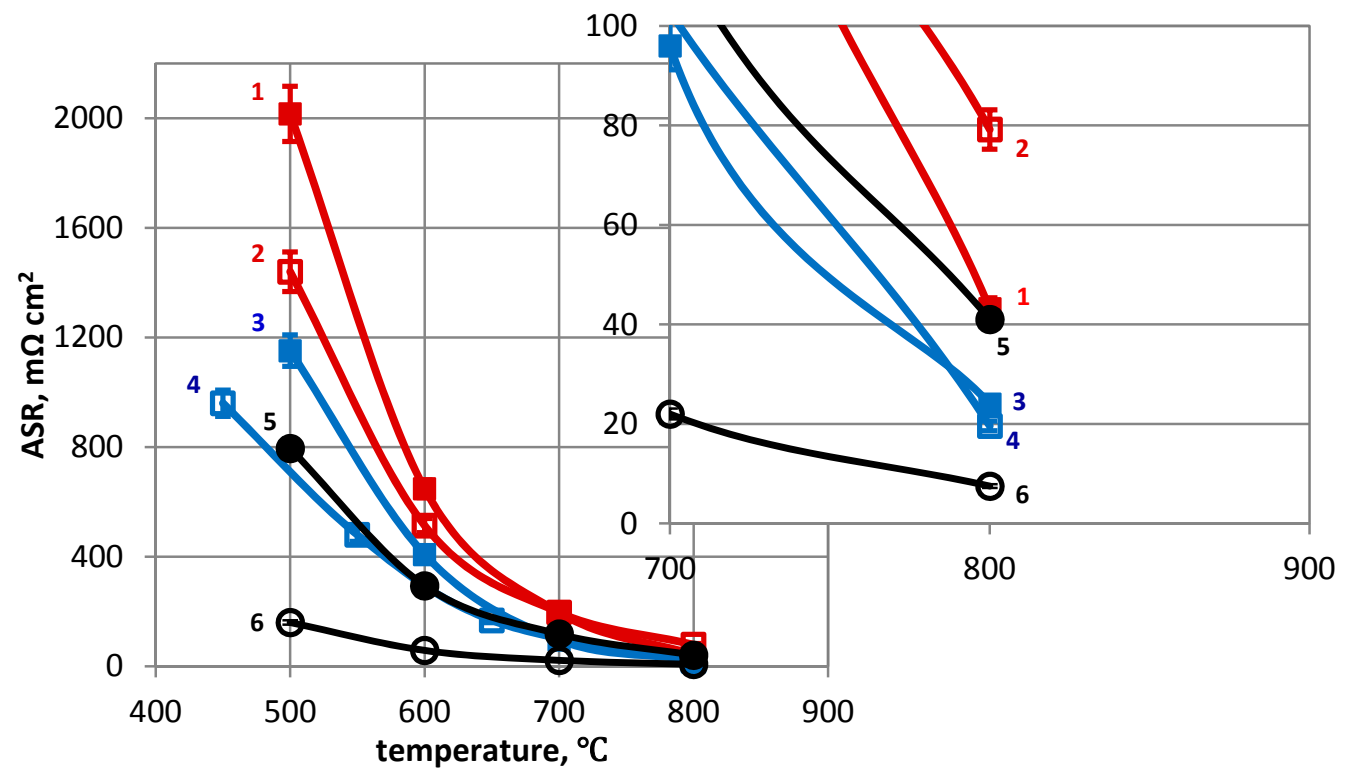

Figure 8. ASR of oxide coatings with the temperature range of $500-800{ }^{\circ} \mathrm{C} .1$ and 2: Co- $40 \mathrm{Mn}$ coating oxidized at $750{ }^{\circ} \mathrm{C}$ in air for $100 \mathrm{~h}$ and $20 \mathrm{~h} ; 3$ and 4: Co-38Mn-2La coating oxidized at $750{ }^{\circ} \mathrm{C}$ in air for $100 \mathrm{~h}$ and $20 \mathrm{~h} ; 5$ and 6: Co-33Mn-17Cu coating oxidized at $750{ }^{\circ} \mathrm{C}$ in air for $100 \mathrm{~h}$ and $20 \mathrm{~h}$. 


\subsection{Discussion}

In previous study $[3,8,25]$, the results disclose that ambient dissociation pressure of oxygen at high temperature will favor the formation of some specific oxides. When coating oxidized in air, partial pressure of oxygen gradually decreases from gas/scale interface to oxide/alloy interface; therefore, a thin $\mathrm{Co}_{3} \mathrm{O}_{4}$ layer forms at high oxygen partial pressure and is usually found on the top oxide layer (Figures $4 \mathrm{a}_{1}$ and 6). Rapid cation diffusion can be caused in the mono-oxide such as $\mathrm{CoO}$ and $\mathrm{MnO}$, but the continuous $(\mathrm{Co}, \mathrm{Mn})_{3} \mathrm{O}_{4}$ spinel oxide layer causes a significant reduction in the oxide rate and cation diffusion. Co-Mn spinel oxides first dispersedly precipitate along grain boundaries of oxide matrix and then evolve into a continuous spinel oxide layer when manganese contents are increasing. Therefore, a continuous $(\mathrm{Co}, \mathrm{Mn})_{3} \mathrm{O}_{4}$ spinel layer may be formed in the outer part of the scale because of the relatively high oxygen activity and the extended oxidation time. This result is found in both Co-38Mn-2La and Co-40Mn coatings in Figure 2. When coating oxidized for $100 \mathrm{~h},(\mathrm{Co}, \mathrm{Mn})_{3} \mathrm{O}_{4}$ spinel continues to grow.

Partial Mn-Co-O phase diagram in air relative to different $\mathrm{Co}$ concentration and temperature is discussed in reference [28], and it shows that $\mathrm{MnCo}_{2} \mathrm{O}_{4}$ spinel is the stable phase in the operation temperature of SOFC. In this study, the main spinel phase $(\mathrm{Mn}, \mathrm{Co})_{3} \mathrm{O}_{4}$ after $\mathrm{Co}-38 \mathrm{Mn}-2 \mathrm{La}$ coating and $\mathrm{Co}-40 \mathrm{Mn}$ coating oxidized at $750{ }^{\circ} \mathrm{C}$ for $100 \mathrm{~h}$ is different of Mn-Co ratio than 1:2, and Mn content is a little higher than that in $\mathrm{MnCo}_{2} \mathrm{O}_{4}$ spinel. This becomes complicated because the original concentration ratio of $\mathrm{Co}$ and $\mathrm{Mn}$, the thickness of alloy coating, oxidation temperature and element diffusion in oxides all play an important role in the formation of the $(\mathrm{Co}, \mathrm{Mn})_{3} \mathrm{O}_{4}$ spinel oxide. When $\mathrm{Cu}$ was added into Co-Mn coating, $\mathrm{MnCo}_{2} \mathrm{O}_{4}$ spinel successfully forms on the surface of oxides for both $20 \mathrm{~h}$ and $100 \mathrm{~h}$. In general, $\mathrm{MnCo}_{2} \mathrm{O}_{4}$ spinel has the higher electrical conductivity than $(\mathrm{Co}, \mathrm{Mn})_{3} \mathrm{O}_{4}$ spinel, so $\mathrm{Cu}$ dopant is helpful for improving high temperature electrical behavior of Co-Mn coating, especially for $500-700{ }^{\circ} \mathrm{C}$. However, the formation of micro-pores in oxides will also affect high temperature behavior of coating.

According to EDS in Tables 2-4 outward diffusion of $\mathrm{Cr}$ is suppressed by composited oxide coatings. Fe diffuses into oxide coating but is suppressed by $(\mathrm{Mn}, \mathrm{Co})_{3} \mathrm{O}_{4} / \mathrm{MnCo}_{2} \mathrm{O}_{4}$ spinel and then aggregates under the $(\mathrm{Mn}, \mathrm{Co})_{3} \mathrm{O}_{4} / \mathrm{MnCo}_{2} \mathrm{O}_{4}$ layer (points 1 and 2 in Tables 2 and 3, points 3 and 4 in Table 4). It is apparent that the presence of the $(\mathrm{Mn}, \mathrm{Co})_{3} \mathrm{O}_{4} / \mathrm{MnCo}_{2} \mathrm{O}_{4}$ spinel layer blocks outward diffusion of Fe. When chromium from substrate forms a continuous oxide at the interface, Fe outward diffuses will be also suppressed (points 3 in Tables 2 and 3). Metallic Co diffuses both outward into the oxide layer and inward into 430 SS substrate during oxidation (point 4 in Table 2).

\section{Conclusions}

The metallurgical bond Co-33Mn-17Cu, Co-38Mn-2La and Co-40Mn coatings are successfully deposited on the surface of $430 \mathrm{SS}$ using high-energy micro-arc alloying process. $\mathrm{MnCo}_{2} \mathrm{O}_{4}$ and $\mathrm{Mn}_{2} \mathrm{O}_{3}$ are mainly oxide products when Co-33Mn-17Cu coating oxidized at $750{ }^{\circ} \mathrm{C}$ for $20 \mathrm{~h}$ and $100 \mathrm{~h}$. ASR of Co-33Mn-17Cu oxide coating is the smallest among the three coatings when oxidized for $20 \mathrm{~h}$. La-rich oxides are locally precipitated in the oxide layer after Co-38Mn-2La coating oxidized for $100 \mathrm{~h}$, and some granular appearance of $\mathrm{Co}_{3} \mathrm{O}_{4}$ oxide on the top surface are found for $20 \mathrm{~h}$, which is not found in $\mathrm{Co}-33 \mathrm{Mn}-17 \mathrm{Cu}$ and $\mathrm{Co}-40 \mathrm{Mn}$ coatings. A thin $\mathrm{Co}_{3} \mathrm{O}_{4}$ spinel layer with a small amount of $\mathrm{Mn}$ oxides favors forming on the top oxide layer, and the $(\mathrm{Mn}, \mathrm{Co})_{3} \mathrm{O}_{4}$ spinel between $\mathrm{MnCo}_{2} \mathrm{O}_{4}$ (cubic) and $\mathrm{Mn}_{3} \mathrm{O}_{4}$ (tetragonal) gradually grows on the surface of oxide layer with the extended oxidation time for $\mathrm{Co}-38 \mathrm{Mn}-2 \mathrm{La}$ and $\mathrm{Co}-40 \mathrm{Mn}$ coatings. The value of area-specific resistance at $800{ }^{\circ} \mathrm{C}$ for Co-38Mn-2La coating oxidized for $100 \mathrm{~h}$ is about $24 \mathrm{~m} \Omega \mathrm{cm}^{2}$, which is the smallest among three coatings. Outward diffusion of $\mathrm{Fe}$ and $\mathrm{Cr}$ from substrate is remarkably suppressed by $(\mathrm{Mn}, \mathrm{Co})_{3} \mathrm{O}_{4} / \mathrm{MnCo}_{2} \mathrm{O}_{4}$ spinel oxide layers. The results demonstrate that $\mathrm{Cu} / \mathrm{La}$ dopant leads to different structures and properties of Mn-Co spinel coating, which is possibly used as coating material for the intermediate temperature SOFC. 
Acknowledgments: This work was financially supported by the National Natural Science Foundation of China (51201073), the China Scholarship Fund (2017), the research fund of Jiangsu University of Science and Technology (1624821607-5), the Postgraduate Research \& Practice Innovation Program of Jiangsu Province (KYCX17_1830), and the Priority Academic Program Development of Jiangsu Higher Education Institutions.

Author Contributions: Pingyi Guo and Yong Shao conceived and designed the experiments; Yongbiao Lai, Yu Zhang and Hang Sun performed the experiments; Pingyi Guo, Yuxin Wang and Yong Shao analyzed the data; Yong Shao contributed reagents/materials/analysis tools; Pingyi Guo and Yuxin Wang wrote the paper.

Conflicts of Interest: The authors declare no conflict of interest. The founding sponsors had no role in the design of the study; in the collection, analyses, or interpretation of data; in the writing of the manuscript, and in the decision to publish the results.

\section{References}

1. Kruk, A.; Adamczyk, A.; Gil, A.; Kąc, S.; Dąbek, J.; Ziąbka, M.; Brylewski, T. Effect of Co deposition on oxidation behavior and electrical properties of ferritic steel for solid oxide fuel cell interconnects. Thin Solid Films 2015, 590, 184-192. [CrossRef]

2. Ajitdoss, L.C.; Smeacetto, F.; Bindi, M.; Beretta, D.; Salvo, M.; Ferrari, M. $\mathrm{Mn}_{1.5} \mathrm{Co}_{1.5} \mathrm{O}_{4}$ protective coating on Crofer22APU produced by thermal co-evaporation for SOFCs. Mater. Lett. 2013, 95, 82-85. [CrossRef]

3. Zhang, Y.; Guo, P.Y.; Shao, Y.; Lai, Y.B.; Zhang, J.Q. Preparation and high-temperature performance of Co-10Mn and Co-40Mn alloy coatings for solid oxide fuel cell metal interconnects. J. Alloy. Compd. 2016, 680, 685-693. [CrossRef]

4. Hoyt, K.O.; Gannon, P.E.; White, P.; Tortop, R.; Ellingwood, B.J.; Khoshuei, H. Oxidation behavior of $(\mathrm{Co}, \mathrm{Mn})_{3} \mathrm{O}_{4}$ coatings on preoxidized stainless steel for solid oxide fuel cell interconnects. Int. J. Hydrog. Energ. 2012, 37, 518-529. [CrossRef]

5. Uehar, T.; Yasuda, N.; Okamoto, M.; Baba, Y. Effect of Mn-Co spinel coating for Fe-Cr ferritic alloys ZMG232L and 232J3 for solid oxide fuel cell interconnects on oxidation behavior and Cr-evaporation. J. Power Sources 2011, 196, 7251-7256. [CrossRef]

6. Guo, P.Y.; Shao, Y.; Zeng, C.L.; Wu, M.F.; Li, W.L. Oxidation characterization of FeAl coated 316 stainless steel interconnects by high-energy micro-arc alloying technique for SOFC. Mater. Lett. 2011, 65, 3180-3183. [CrossRef]

7. Guo, P.Y.; Zeng, C.L.; Wang, N.; Shao, Y. FeAl-based coatings deposited by high-energy micro-arc alloying process for wet-seal areas of molten carbonate fuel cell. J. Power Sources 2012, 217, 485-490. [CrossRef]

8. Lai, Y.B.; Guo, P.Y.; Shao, Y.; Tang, P.J.; Zhang, Y.; Zhang, J.F. Formation and performances of spinel reaction layers on Co-40Mn coatings under an oxygen pressure of $10^{5} \mathrm{~Pa}$ for solid oxide fuel cell interconnect application. Vacuum 2016, 130, 14-24. [CrossRef]

9. Feng, Z.J.; Zeng, C.L. Oxidation behavior and electrical property of ferritic stainless steel interconnects with a Cr-La alloying layer by high-energy micro-arc alloying process. J. Power Sources 2010, 195, 7370-7374. [CrossRef]

10. Gavrilov, N.V.; Ivanov, V.V.; Kamenetskikh, A.S.; Nikonov, A.V. Investigations of Mn-Co-O and Mn-Co-Y-O coatings deposited by the magnetron sputtering on ferritic stainless steels. Surf. Coat. Technol. 2011, 206, 1252-1258. [CrossRef]

11. Magrasó, A.; Windisch, H.F.; Froitzheim, J.; Svensson, J.E.; Haugsrud, R. Reduced long term electrical resistance in $\mathrm{Ce} / \mathrm{Co}$ coated ferritic stainless steel for solid oxide fuel cell metallic interconnects. Int. J. Hydrog. Energ. 2015, 40, 8579-8585. [CrossRef]

12. Harthøj, A.; Holt, T.; Møller, P. Oxidation behaviour and electrical properties of cobalt/cerium oxide composite coatings for solid oxide fuel cell interconnects. J. Power Sources 2015, 281, 227-237. [CrossRef]

13. Kolisetty, A.; Fu, Z.Z.; Koc, R. Development of $\mathrm{La}(\mathrm{CrCoFeNi}) \mathrm{O}_{3}$ system perovskites as interconnect and cathode materials for solid oxide fuel cells. Ceram. Int. 2017, 43, 7647-7652. [CrossRef]

14. Solovyev, A.A.; Ionov, I.V.; Shipilova, V.; Kovalchuk, A.N.; Syrtanov, M.S. Magnetron-sputtered $\mathrm{La}_{0.6} \mathrm{Sr}_{0.4} \mathrm{Co}_{0.2} \mathrm{Fe}_{0.8} \mathrm{O}_{3}$ nanocomposite interlayer for solid oxide fuel cells. J. Nanopart. Res. 2017, 19, 87-95. [CrossRef]

15. Sun, H.Y.; Sen, W.; Ma, W.H.; Yu, J.; Yang, J.J. Fabrication of LSGM thin films on porous anode supports by slurry spin coating for IT-SOFC. Rare Met. 2015, 34, 797-801. [CrossRef] 
16. Guo, P.Y.; Zeng, C.L.; Shao, Y.; Qin, Z.S. Effect of $\mathrm{LaCrO}_{3}$ coating on high temperature oxidation of type 316 stainless steel. J. Rare Earth 2011, 29, 698-701. [CrossRef]

17. Riffard, F.; Fondard, J.; Moulin, P.; Perrier, S.; Buscail, H. Lanthanum effect on the isothermal high temperature oxidation behavior at $1000{ }^{\circ} \mathrm{C}$ of a phosphoric acid-treated AISI 304 stainless steel. Oxid. Met. 2014, 81, 191-201. [CrossRef]

18. Buscail, H.; Issartel, C.; Riffard, F.; Rolland, R.; Perrier, S.; Fleurent, A. Influence of lanthanum coatings on a model 330 alloy (Fe-35Ni-18Cr-2Si) oxidation at high temperatures. Oxid. Met. 2014, 81, 127-138. [CrossRef]

19. Mhin, S.; Han, H.; Kim, K.M.; Lim, J.; Kim, D.; Lee, J.; Ryu, J.H. Synthesis of (Ni,Mn,Co)O ${ }_{4}$ nanopowder with single cubic spinel phase via combustion method. Ceram. Int. 2016, 42, 13654-13658. [CrossRef]

20. Xiao, J.; Zhang, W.; Xiong, C.; Pu, J.; Jian, L. Oxidation behavior of Cu-doped $\mathrm{MnCo}_{2} \mathrm{O}_{4}$ spinel coating on ferritic stainless steels for solid oxide fuel cell interconnects. Int. J. Hydrog. Energ. 2016, 41, 9611-9618. [CrossRef]

21. Masi, A.; Bellusci, M.; McPhail, S.J.; Padella, F.; Reale, P.; Hong, J.E.; Wilckens, R.S.; Carlini, M. Cu-Mn-Co oxides as protective materials in SOFC technology: The effect of chemical composition on mechanochemical synthesis, sintering behaviour, thermal expansion and electrical conductivity. J. Eur. Ceram. Soc. 2017, 37, 661-669. [CrossRef]

22. Xu, Y.J.; Wen, Z.Y.; Wang, S.R.; Wen, T.L. Cu doped Mn-Co spinel protective coating on ferritic stainless steels for SOFC interconnect applications. Solid State Ion. 2011, 192, 561-564. [CrossRef]

23. Park, B.K.; Lee, J.W.; Lee, S.B.; Lim, T.H.; Park, S.J.; Park, C.O.; Song, R.H. Cu- and Ni-doped $\mathrm{Mn}_{1.5} \mathrm{Co}_{1.5} \mathrm{O}_{4}$ spinel coatings on metallic interconnects for solid oxide fuel cells. Int. J. Hydrog. Energ. 2013, 38, 12043-12050. [CrossRef]

24. Brylewski, T.; Kruk, A.; Bobruk, M.; Adamczyk, A.; Partyka, J.; Rutkowski, P. Structure and electrical properties of $\mathrm{Cu}$-doped $\mathrm{Mn}$-Co-O spinel prepared via soft chemistry and its application in intermediate temperature solid oxide fuel cell interconnects. J. Power Sources 2016, 333, 145-155. [CrossRef]

25. Guo, P.Y.; Lai, Y.B.; Shao, Y.; Zhang, Y.; Wang, Y.X. Thermal Growth $\mathrm{Cu}_{1.2} \mathrm{Mn}_{1.8} \mathrm{O}_{4}$ Spinel Coatings on Metal Interconnects for Solid Oxide Fuel Cell Applications. Metals 2017, 7, 522. [CrossRef]

26. Lai, Y.B.; Guo, P.Y.; Shao, Y.; Zhang, Y.; Liu, N. The Role of Dy Doping on Oxidation Behavior of Co-40Mn/Co Coating for Solid Oxide Fuel Cell Metal Interconnects. J. Alloy. Compd. 2017, 694, 383-393. [CrossRef]

27. Yokoyama, T.; Meguro, T.; Kato, K.; Okazaki, S.; Ito, D.; Tatami, J.; Wakihara, T.; Kome, K. Preparation and electrical properties of sintered oxide composed of $\mathrm{MnFeNiO} 4$ with a cubic spinel structure. J. Electroceram. 2013, 31, 353-359. [CrossRef]

28. Bateni, M.R.; Wei, P.; Deng, X.H.; Petric, A. Spinel coatings for UNS 430 stainless steel interconnects. Surf. Coat. Technol. 2007, 201, 4677-4684. [CrossRef]

(C) 2018 by the authors. Licensee MDPI, Basel, Switzerland. This article is an open access article distributed under the terms and conditions of the Creative Commons Attribution (CC BY) license (http://creativecommons.org/licenses/by/4.0/). 